\title{
The Internationalization of Small \& Medium Enterprises (SMEs) in Automation Industry of Penang, Malaysia
}

\author{
Yeoh Khar Kheng \\ School of Business Management, 06010, University Utara Malaysia, Malaysia \\ *E-mail of the corresponding author: kharkheng@uum.edu.my
}

\begin{abstract}
With the rise of globalization, internationalization of companies has become a new business order, as globally, boundaries are no longer a barrier to firms as they can develop competence to enter international market and gain competitive advantage at global marketplace. The significance of this proposal is by integrating in a single framework the relationship between a pull factor (networking) and push factors (management attitude and entrepreneurial orientation) on the internationalization of SMEs in automation industry as well as testing the moderation effect of marketing characteristics (market attractiveness) on these constructs. This study proposes a research framework that examined the association between networking, management attitude, entrepreneurial orientation and internationalization of SMEs in the automation industry of Penang, Malaysia, with marketing characteristics (market attractiveness) as moderator. Underpinned by the Eclectic Model (OLI Framework) and Network Theory, the proposal examines the function of networking to obtain resources and access market opportunities; the positive management attitude and entrepreneurial orientation of firms as strategic intangible resources, and the marketing characteristics to function as moderator between the predicting and criterion variables. Theoretically, the study investigates empirically the association amongst the three independent variables (networking, management attitude and entrepreneurial orientation) and the dependent variable (internationalization of SMEs). In addition, this study has incorporated a moderating variable (marketing characteristics) into the research model. This proposal was unique in the sense that it is pivoted in SMEs automation industry in Penang, Malaysia. Thus, this proposal will enrich literature on the moderating effect of marketing characteristics (market attractiveness) and the relationship amongst the variables in SMEs automation industrial setting and context.
\end{abstract}

Keywords: internationalization, automation, Small \& Medium Enterprise, Penang, Malaysia.

DOI: $10.7176 / \mathrm{EJBM} / 13-18-03$

Publication date:September $30^{\text {th }} 2021$

\section{Introduction}

In the context of Malaysia, The Machinery and Equipment (M\&E) sector has been identified as one of the catalytic sub-sectors under the 11th Malaysia Plan (2016-2020) due to its cross-cutting linkages with all economic segments such as the primary, manufacturing and services sectors (Malaysia Investment Development Authority, 2020). The growth will focus on the manufacturing of high value-added and high technology Machinery \& Equipment. Small \& Medium Enterprises (SMEs) in Malaysia, like their counterparts across the globe, pursue internationalization to gain competitive advantage, increase profitability and enhance business growth and survival (Godwin, Ntayi, Ngoma, Bakunda, \& Kabagambe, 2020, Reuber et al., 2014). However, considering the importance of SMEs in the value chain of production, as service providers and producers of finished products, the Malaysian SMEs are yet to fully regenerate resources and earn higher profit from their operations in overseas (Lee, 2018). Malaysian SMEs have all the potentials to grow at international market and profit optimally from internationalization, considering the level of support they received from government. However, the market share of the SMEs at international market is far lower than their corresponding market share in the local marketplace, and also, the total export share of the SMEs is less than 20\% (Mahmood, 2014).

Notwithstanding, the automation industry of Malaysia had witnessed certain degree of diversification (Malaysia Investment Development Authority, 2020). However, the industry is faced with stagnation as firms in this industry lack adequate networking (collaborative partners) and needed management attitude to achieve successful internationalization (Malaysia Automation Technology Association, 2019). Similarly, the managers need to develop the right entrepreneurial spirit by taking risk, being proactive and innovative), in order to survive in the highly unpredictable international market environment (Sendawula, Ngoma, Bananuka, Saadat Nakyejwe, \& Kabuye, 2021, Hern ández-Perlines \& Xu, 2018). Likewise, literature has shown few research investigations on factors that influence SMEs' internationalization in the automation industry of Malaysia (Witte, 2012). This research proposal is built on the argument that managers of SMEs in the automation industry of Malaysia must integrate together both the pull factor (networking) and push factors (management attitude and entrepreneurial orientation), to facilitate the internationalization process of their SMEs. Also, this study is built on the argument that the relationship between the pull and push factors and internationalization is moderated by marketing characteristics (i.e., market attractiveness). Based on the above assertion, this study is designed to empirically 
investigate the moderating effect of marketing characteristics (market attractiveness) on the relationship between networking, management attitude, entrepreneurial orientation and internationalization of SMEs in the automation industry of Malaysia.

\section{Literature Reviews and Propositions}

The current study is underpinned by the Eclectic Model (OLI Framework) and Network Theory. According to Afsharghasemi et al. (2013), the eclectic model (OLI framework) was developed Dunning (1988) to describe specific foreign investment ownership advantages (O), location-specific advantages (L), as well as internationalization advantages (I). Basically, the Dunning's model underlies the importance of certain assumptions such as: (1) possession of ownership privilege by a firm over competitors in host country market (ownership advantage) is of paramount; (2) a firm must use the existing advantages to exercise command over other local firms (internationalization advantage); and (3) the location should be desirable as it offers some positivity like factor inputs, for firm to locate its operations in a market that is far away from home country (location advantages). Ciszewska-Mlinaric et al. (2017) emphasized that the OLI framework seeks to explain the critical role of combination of ownership, location and internationalization advantages as motivating factors for internationalization, and successful internationalization process of business enterprises. Therefore, the OLI framework explains the impacts of other environmental factors such as government policies, financial markets, legal rules, history and culture on firms' strategic decisions, as well as firms' internationalization process.

As for the network model, it was developed by Johanson and Mattsson (1988). The model adopts external view using "networks of relationships between firms" typologies to depict the importance of industrial networks on the internationalization of industrial firms. The network is described as a voluntary agreement between firms or collaborative associations with competitors (Sendawula et al., 2021). Fuller-Love \& Thomas, 2004). Thus, suggesting that firms' internationalization is a product of association with multiple participants (Mtigwe, 2006). Javalgi and Todd (2011) contended that the network model provides better explanations on the relevance of activities within the network to facilitate internationalization process, by helping participating firms to access market opportunities and pool of resources. Hence, through business networks a firm can establish relationships with different actors such as competitors, customers, friends, government bodies and suppliers, to access resources and markets and strengthen its internationalization efforts (Sendawula et al., 2021, Johanson \& Mattsson, 1988).

\subsection{Networking and Internationalization of SMEs}

According to the extant literature, networking is considered as either a social capital factor (Godwin et al., 2020, Musteen et al., 2011), or an organizational capability (Mu \& Di Benedetto, 2012), that greatly impact the degree of internationalization of firms. Networking as a social capital factor, is described as any form of relationships that managers use to realize the objectives of firms (Ciravegna et al., 2014). Burt (1992) described social network as "the totality of persons connected by social relationships within a bounded population". Therefore, stressing that firms enter into social networks in order to relate with business contacts (clients, suppliers and managers of networked companies), or personal contacts (friends, relatives or family ties), and obtain resources to achieve organizational objectives. literature showed that networking relationship is valuable to companies (Lin et al., 2014), especially those that want to enter distant markets or seek for faster internationalization (Vissak et al., 2017), and intend to become international new ventures or born global (Monferrer et al., 2015). Hence, networking relationship is valuable in accessing resources (know-how, market information and knowledge), development of capabilities and discovery of new business opportunities, which are necessary for successful internationalization (Sendawula et al., 2021).

Notwithstanding, Musso and Francioni (2015) contended that though networking is critical for internationalization, because through relationships between firm and other various actors such as public administration, competitors, suppliers, customers and non-profit organizations, firm can accumulate resources and knowledge; however, networking does not always enhance foreign market development or entry process. Similarly, Eriksson et al. (2014) found that some networking relationships result to difficulties during internationalization, as such, it could not foster internationalization, specifically if a firm depend on few numbers of partners. Equally, Ciravegna et al. (2014) asserted that the relationship between networking and internationalization is not always positive and significant. Hence, the relationship between the two variables is contradictory. In view of the above contrasting empirical results, this study hypothesizes that,

$H_{1}$ : Networking has positive significant relationship with the internationalization of SMEs in the automation industry of Penang, Malaysia.

\subsection{Management Attitude and Internationalization of SMEs}

Researchers have investigated the influence of management attitude on firms' internationalization activities, such as exporting activities (Javalagi \& Todd, 2011), export intention and export intensity (Suarez-Ortega \& Alamo- 
Vera, 2005). According to the findings, though, management has no impact on export intensity, but management attitude has positive influence on export intention and export performance. Accordingly, the influence of management attitude on firms' internationalization has been investigated both in the manufacturing and service sectors (Javalagi \& Todd, 2011). In the manufacturing sector, Dichtl, Köglmayr and Müller (1990) found that attitude of managers is important determinant for firms to operate internationally and enhance export performance.

Nevertheless, the extant literature demonstrated that the influence of management attitude on firm internationalization is inconclusive. For instance, Burpitt and Rondinelli (2000) found that management attitude has no positive influence on firm internationalization. However, Axinn (1988) cautioned that firms seeking internationalization (international expansion) should not undervalue the influence of management attitude. Adding that management attitude implies that managers become more concern with international expansion, and less concern with complexities in the foreign markets. Based on the above narration, this study hypothesizes that, $\mathrm{H}_{2}$ : Management Attitude has positive significant relationship with the internationalization of SMEs in the automation industry of Penang, Malaysia.

\subsection{Entrepreneurial Orientation and Internationalization of SMEs}

Hoskisson, Covin, Volberda and Johnson (2011) defined entrepreneurial orientation as firms' attitude to strategically engage in proactive, innovative and risk-taking behaviors. Hence, entrepreneurial orientation signifies a level of firms' priority to proactively develop corporate strategy (identify and exploit market opportunities), take-risk and innovatively respond to market opportunities (Lumpkin \& Dess, 1996). Thus, entrepreneurial orientation denotes to proactive method of exploiting or identifying new market opportunities, and enthusiasm in risk-taking to renew market offerings by developing new methods and products than competitors (Genc, Dayan \& Genc, 2019).

According to literature, entrepreneurial orientation is vital for SMEs to exploit business opportunities (Raj Javalgi \& Scherer, 2018), in both developed and emerging markets. Hence, entrepreneurial orientation is critical for firms to overcome a liability of foreignness by developing technical and managerial competence (Brouthers, Nakos \& Dimitratos, 2015). Similarly, literature showed that a greater entrepreneurial orientation of firms (i.e., proactivity and risk taking) facilitates search for international opportunities (Kiss et al., 2012), and tendency to internationalize early (Ciravegna, Majano \& Zhan, 2014). Hence, in terms of identification of foreign market, matching pre-entry of foreign market requirements and launching of entry strategy, a firm must proactively scan for opportunities at the market, create awareness of consumer needs, and identify capabilities and resources of business partners; and as well, take risk and innovatively develop a meaningful product or services, to secure future performance at international context (Raj Javalgi \& Scherer, 2018). Thus, this study hypothesizes that,

$H_{3}$ : Entrepreneurial Orientation has positive significant relationship with the internationalization of SMEs in the automation industry of Penang, Malaysia.

\subsection{Marketing Characteristics as Moderator}

A number of scholars found that internationalization of SMEs is influenced by internal and external environmental factors as well as exploitative and explorative actions of business enterprise (Masiello \& Izzo, 2019). Huang et al. (2010) have established the effects of environmental conditions on firms' success and international performance. Likewise, Evans et al. (2008) found that cultural difference and difference in business practices (psychic distance) between domestic and foreign markets, results to greater resources commitment at international marketplace. In addition, Javalgi et al. (2003) established that location-specific characteristics or host country factors (market attractiveness) of foreign market have a direct linkage with attitude of management towards operating internationally, and degree of internationalization of firms. Yet, Picot-Coupey et al. (2014) found the direct positive influence of market characteristics (foreign market attractiveness) on the international expansion mode choice of an enterprise. Therefore, this study hypothesizes the following,

$\mathrm{H}_{4}$ : Marketing characteristics moderates the relationship between networking and internationalization of SMEs in the automation industry of Penang, Malaysia.

$H_{5}$ : Marketing characteristics moderates the relationship between management attitude and internationalization of SMEs in the automation industry of Penang, Malaysia.

$H_{6}$ : Marketing characteristics moderates the relationship between entrepreneurial orientation and internationalization of SMEs in the automation industry of Penang, Malaysia.

\section{Proposed Research Framework}

This study presents a research framework which was developed based on the extensive literature review and the existing gaps in the literature. The aim of the research framework is to demonstrate the pattern of relationship existing between the independent variables (networking, management attitude and entrepreneurial orientation), and the dependent variable (SMEs' internationalization), as well as the moderating variable (marketing 
characteristics - foreign market attractiveness). The framework is shown in Figure 1.1.

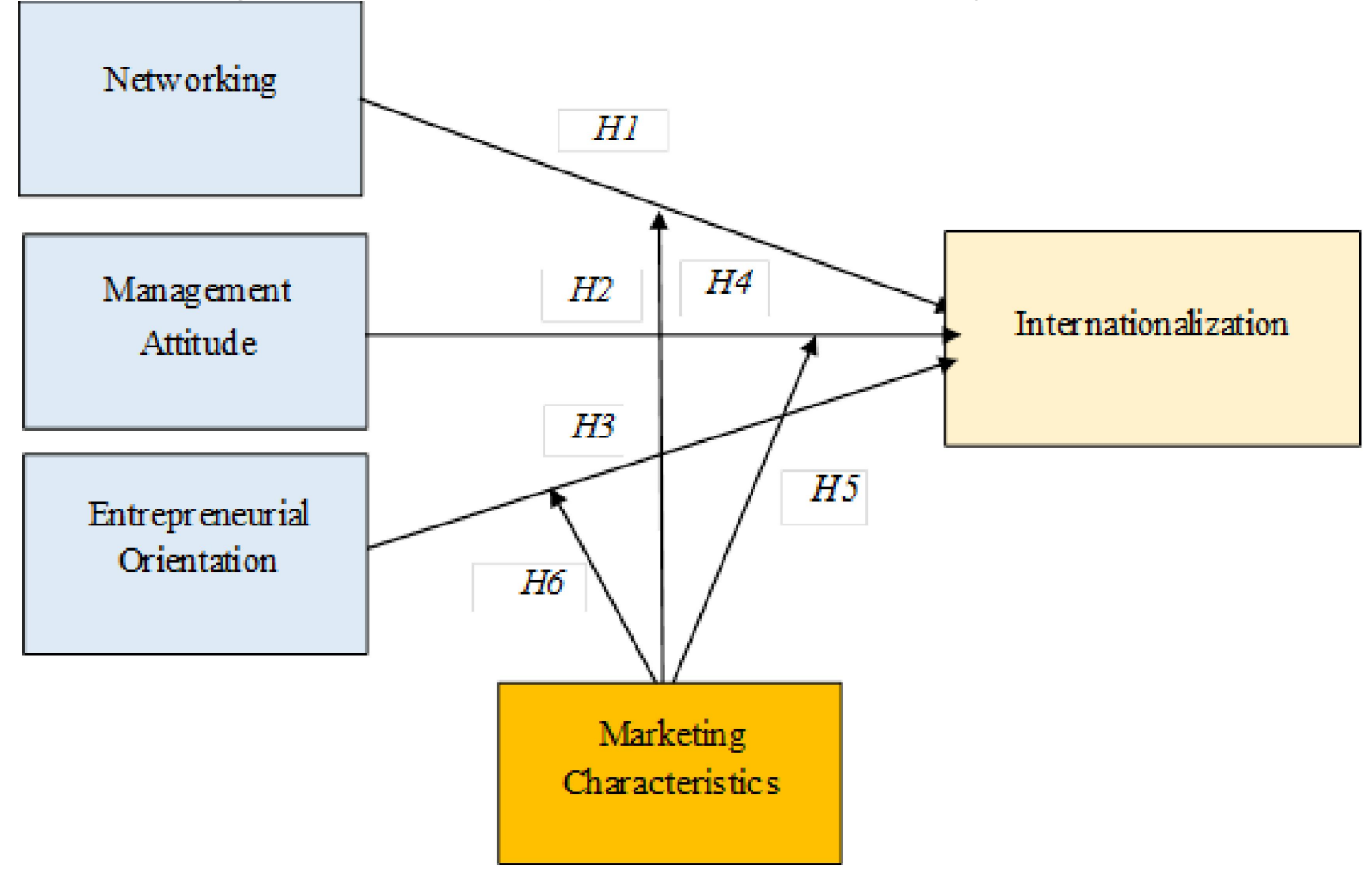

Figure 1. Research Framework

\section{Conclusion}

This theoretical proposal is of immense significance, both in theory and practice. Theoretically, first, the study investigates empirically the relationship between three independent variables (networking, management attitude and entrepreneurial orientation) and one dependent variable (internationalization of SMEs). Second, unlike the previous studies, this study has incorporated a moderating variable (marketing characteristics) into the model. Third, this study is unique in the sense that it is to be done in the context of SMEs in the automation industry of Malaysia. Thus, this study will enrich literature on the moderating effect of marketing characteristics (market attractiveness) on the relationship between the variables in a new industrial setting and context. Hence, the automation industry in Penang is a key sector that contributes greatly to the growth of Malaysian economy.

Therefore, this study, by integrating in a single framework and investigating the relationship between a pull factor (networking) and push factors (management attitude and entrepreneurial orientation) and internationalization of SMEs in automation industry, succeeds in bringing a new insight on how the two factors interact to boost SMEs' internationalization. Unlike prior researches that examine the relationship between pull factors, push factors and internationalization of SMEs in isolation, by testing the effect of marketing characteristics (market attractiveness) on these constructs provides further empirical evidence on the type of interaction between the research variables.

Practically, this study is of significance in helping SMEs to understand that there are many opportunities that are available at international marketplace. Similarly, this study will help managers especially those in the automation industry to understand various factors that can facilitate successful internationalization of SMEs. Hence, SMEs must understand that internationalization is key for their survival in the marketplace. Equally, this study will provide data to SMEs' managers. Hence, it is necessary for them to formulate strategy to enhance their performance, sustain their position in the market and as well, succeed both at domestic and international marketplace. In addition, this study will provide data to the government, as it needs to properly coordinate the internationalization of SMEs, and also, formulate sound policies for SMEs to perform optimally at international market. Hence, SMEs in the automation industry need to be encouraged because they are leading other SMEs sub-sectors in championing a technology driven and highly developed economy. In order to bring new insights, future research may adopt qualitative approach or mix-mode or adopt longitudinal research design or may design the survey questionnaire using a combination of subjective and objective measures.

\section{References}

Afsharghasemi, A., Zain, M., Sambasivan, M. \& Ng Siew Imm, S. (2013), "Market Orientation, Government Regulation, Competitive Advantage and Internationalization of SMEs: A Study in Malaysia", Journal of Business Administration Research, 2(2). 
Axinn, C.N. (1988), “Export performance: do managerial perceptions make a difference?", International Marketing Review, 5(2), 61-71.

Brouthers, K.D. Nakos, G., \& Dimitratos, P. (2015), "SME entrepreneurial orientation, international performance, and the moderating role of strategic alliances", Entrepreneurship: Theory \& Practice, 39(5), 1161-1187.

Burpitt, WJ. \& Rondinelli, DA. (2000), “Small firms' motivations for exporting: To earn and learn?", J. Small Bus. Manage., 10, 1-14.

Burt, R. S. (1992), "Structural Holes: The Social Structure of Competition", Cambridge, MA: Harvard University Press.

Ciravegna, L., Majano, S. B., \& Zhan, G. (2014), "The inception of internationalization of small and medium enterprises: The role of activeness and networks", Journal of Business Research, 67(6), 1081-1089.

Ciszewska-Mlinaric, M., Obloj, K. \& Wasowska, A. (2017), "Internationalization choices of Polish firms during the post-socialism transition period: The role of institutional conditions at firm's foundation", Business History. DOI: 10.1080/00076791.2017.1332045.

Ciszewska-Mlinari c, M. \& Mlinarǐc, F. (2010), "Small Firms in a Small Country: Managerial Factors, Internationalization and Performance of Slovenian SMEs", Managing Global Transitions, 8(3), 239-259.

Dunning, J.H. (1988), "The theory of international production", International Trade Journal, 3, 21-46.

Eriksson, K., Jonsson, S., Lindbergh, J. \& Lindstrand, A. (2014), "Modeling firm specific internationalization risk: An application to banks risk assessment in lending to firms that do international business", International Business Review, 23(6), 1074-1085.

Evans, J., Mavondo, F. \& Bridson, K. (2008), "Psychic distance: antecedents, retail strategy implications and performance outcomes", Journal of International Marketing, 16(2), 32-63.

Fuller-Love, N. \& Thomas, E. (2004), "Networks in small manufacturing firms", Journal of Small Business and Enterprise Development, 11, 244-253. http://dx.doi.org/10.1108/14626000410537182.

Genc, E., Dayan, M. \& Genc, O. F. (2019), "The impact of SME internationalization on innovation: The mediating role of market and entrepreneurial orientation", Industrial Marketing Management, https://doi.org/10.1016/j.indmarman.2019.01.008

Godwin, M. A., Ntayi, J. M., Ngoma, M., Bakunda, G., \& Kabagambe, L. B. (2020), "The internationalization of small to medium-sized enterprises: Do all levels in international networking matter?", Journal of Small Business and Enterprise Development, 27(5), 817-837. doi:http://dx.doi.org/10.1108/JSBED-09-2019-0313.

Hern ández-Perlines, F., \& Xu, W. (2018), "Conditional mediation of absorptive capacity and environment in international entrepreneurial orientation of family businesses", Frontiers in Psychology, 9, 102.

Huang, K-P., Wang, C-H., Tseng, M-C. \& Wang, K.Y. (2010), “A study on entrepreneurial orientation and resource acquisition: the effects of social capital", Afr. J. Bus. Manage. 4(15), 3226-3231.

Hoskisson, R. E., Covin, J., Volberda, H. W., \& Johnson, R. A. (2011), Revitalizing entrepreneurship: The search for new research opportunities", Journal of Management Studies, 48(6), 1141-1168.

Javalgi, R.G. \& Todd, P.R. (2011), "Entrepreneurial orientation, management commitment, and human capital: The internationalization of SMEs in India", Journal of Business Research, 64, 1004-1010.

Javalgi, R., Griffith, D., \& White, S. (2003), "An empirical examination of factors influencing the internationalization of service firms", Journal of Services Marketing, 17(2/3), 185-199.

Johanson, J. \& Mattsson, G. (1988), "Internationalization in industrial systems-A Network approach", Strategies in Global Competition. New York: Croom Helm, 287-314.

Kiss, A.N., Danis, W.M., \& Cavusgil, S. (2012), "International entrepreneurship research in emerging economies: A critical review and research agenda", Journal of Business Venturing, 27, 266-290.

Lee, T. Y. (2018), "Success Factors for Rapid Expansion of Malaysia SMEs in Global Market: A Case Study Approach" (Doctoral dissertation, UTAR).

Lin, Y.-H., Chen, C.-J., \& Lin, B.-W. (2014), "The roles of political and business ties in new ventures: Evidence from China”, Asian Business \& Management, 13(5), 411-440.

Lumpkin, G. T. \& Dess, G. G. (1996), "Clarifying the entrepreneurial orientation construct and linking it to performance", Academy of Management Review, 21(1), 135-172.

Mahmoud, M. A., \& Muharam, F. M. (2014), "Factors Affecting the Entrepreneurial Intention of PhD Candidates: A Study of Nigerian International Students of UUM", European Journal of Business and Management, 6(36), 17-24.

Malaysia Automation Technology Association (2019). Retrieved from https://automation.org.my/ (11th June, 2021).

Malaysia Investment Development Authority (2020), Machinery and Equipment Industry. Retrieved from https://www.mida.gov.my/home/machinery-and-equipment.

Masiello, B. \& Izzo, F. (2019), "Interpersonal Social Networks and Internationalization of Traditional SMEs", Journal of Small Business Management, 0(0), 1-34. 
Mtigwe, B. (2006), "Theoretical milestones in international business: The journey to international entrepreneurship theory", Journal of International Entrepreneurship, 4, 5-25. http://dx.doi.org/10.1007/s10843-006-5872-5.

Monferrer, D., Blesa, A., \& Ripollés, M. (2015), "Born global through knowledge-based dynamic capabilities and network market orientation", BRQ Business Research Quarterly, 18 (1), 18-36.

Mu, J. \& Di Benedetto, A. (2012), "Networking Capability and New Product Development", IEEE Transactions on Engineering Management, 59(1).

Musso, F., \& Francioni, B. (2015), "Agri-food clusters, wine tourism and foreign markets. The role of local networks for SME's internationalization”, Procedia Economics and Finance, 27, 334-343.

Musteen, M., \& Datta, D.K. (2011), "Learning about foreign markets: A study of Czech SMEs", Journal of International Entrepreneurship, 9(2), 91-109.

Picot-Coupey, K., Burt, S.L. \& Cliquet, G. (2014), "Retailers' expansion mode choice in foreign markets: Antecedents for expansion mode choice in the light of internationalization theories", Journal of Retailing and Consumer Services, Elsevier, 21(6), 976-991.

Raj Javalgi, L. R., \& Scherer, R. F. (2018), "Intangible Resources Influencing the International Performance of Professional Service SMEs in an Emerging Market: Evidence from India”, International Marketing Review. Https://doi.org/10.1108/IMR-06-2016-0130.

Reuber, A. R., Fischer, E., \& Morgan-Thomas, A. (2014), "Understanding eINVs through the lens of prior research in entrepreneurship, international business and international entrepreneurship", The Routledge companion to international entrepreneurship, 165-185.

Sendawula, K., Ngoma, M., Bananuka, J., Saadat Nakyejwe, L. K., \& Kabuye, F. (2021), "Business networking and internationalization: Testing the mediation role of organizational learning", World Journal of Entrepreneurship, Management and Sustainable Development, 17(2), 246-259. http://dx.doi.org/10.1108/WJEMSD-04-2020-0030

Suarez-Ortega, S. \& Alamo-Vera, F. (2005), "SMEs' Internationalization: firms and managerial factors", International Journal of Entrepreneurial Behavior \& Research, 11(4), 258-279.

Vissak, T., Tsukanova, T., \& Zhang, X. (2017), "The value of knowledge, network relationships and governmental support for Chinese firms' early internationalization: Survey evidence In Value Creation in International Business (195-217)", Palgrave Macmillan, Cham.

Witte, I. (2012), "Evolution of the automation industry in Penang 2005-2011 Exception on the national stagnation?", Universiteit Utrecht. 